\title{
Measurement of the acid-labile subunit of the insulin-like growth factor binding protein complex in human serum: a comparison of four immunoassays
}

\author{
R C Baxter ${ }^{1,2}$, M Svejkar ${ }^{2,3}, M$ J Khosravi ${ }^{4}$, G L Bennett ${ }^{5}$, \\ K V Hardman ${ }^{1}$, A Senese ${ }^{2,3}$, J Mistry ${ }^{4}$, P E Walton ${ }^{4}$ and V Quarmby ${ }^{5}$ \\ ${ }^{1}$ Kolling Institute of Medical Research, University of Sydney, Royal North Shore Hospital, Sydney, New South Wales 2065, Australia \\ ${ }^{2}$ Cooperative Research Centre for Diagnostic Technologies, Brisbane, Queensland 4001, Australia \\ ${ }^{3}$ Bioclone Australia Pty. Limited, Sydney, New South Wales 2204, Australia \\ ${ }^{4}$ Diagnostic Systems Laboratories Inc., Webster, Texas 77598, USA \\ ${ }^{5}$ BioAnalytical Technology, Genentech Inc., S. San Francisco, California 94080, USA \\ (Requests for offprints should be addressed to R C Baxter, Kolling Institute of Medical Research, Royal North Shore Hospital, St Leonards, NSW 2065, \\ Australia; Email: robaxter@med.usyd.edu.au.)
}

\begin{abstract}
The acid-labile subunit (ALS) of the high molecular weight insulin-like growth factor binding protein complex is a liver-derived glycoprotein which is regulated by growth hormone and serves as a serum marker of growth hormone action. We have compared the measurement of ALS by four immunoassay methods (two RIAs, two ELISAs) utilizing various polyclonal and monoclonal antibodies raised against natural or recombinant human ALS, or synthetic ALS peptides. Despite the variety of methodologies and reagents, results obtained by the four methods were highly correlated for 125 sera from various patient groups, and when compared for individual groups of sera
\end{abstract}

from healthy children and adults, growth hormonedeficient children and adults, and subjects with acromegaly. Some weaker correlations among methods were seen when measuring ALS levels in groups of sera from pregnant subjects and subjects with chronic renal failure. An assay using antibodies raised against recombinant ALS yielded lower apparent values than the other methods in patient sera, the discrepancy probably being attributable to a difference in standardization. We conclude that a variety of assay formats and reagents can yield serum ALS values of potential clinical utility.

Journal of Endocrinology (2000) 165, 271-279

\section{Introduction}

The optimal assessment of growth hormone $(\mathrm{GH})$ secretory status has been a problem for endocrinologists for many years (Ranke \& Haber 1992, Hoffman et al. 1994). Since GH itself has a pulsatile pattern of secretion and is influenced by stress, exercise and other factors, a random serum GH measurement is of limited diagnostic value. Multiple sampling at short time intervals, quantitation of the peak GH response to physiological or pharmacological stimuli, and the measurement of GH-dependent proteins such as insulin-like growth factor (IGF)-I, are among the many approaches that have been taken to overcome this problem (Albertsson-Wikland \& Rosberg 1992). While multiple sampling yields a direct measure of the $\mathrm{GH}$ secretory profile, its applicability is limited, due to the many GH determinations needed for each profile. Less sampling is required to determine the $\mathrm{GH}$ response to stimulation by exercise, insulin-induced hypoglycemia, or agents such as arginine, clonidine, GH-releasing hormone and short synthetic GH-releasing peptides (Ranke \& Haber 1992). However, these agents do not always provoke a GH response in every patient, and the establishment of the threshold response required to define normal GH secretion has been controversial.

$\mathrm{GH}$ acts on the liver and other tissues to stimulate the production of IGF-I, an anabolic and mitogenic peptide which mediates the growth-promoting activity of $\mathrm{GH}$ (Humbel 1990). The normal synthesis of IGF-I is dependent on the activation of hepatic GH receptors. Serum IGF-I levels are markedly reduced in GH-deficient subjects, or in subjects with adequate GH secretion but absent, inactive or down-regulated GH receptors (Donaghy \& Baxter 1996, Rosenfeld 1996). Like the structurally related but less GH-dependent peptide, IGFII, IGF-I is carried in the circulation in complexes with IGF binding proteins (IGFBPs). This family of six homologous proteins is characterized by strong conservation of structure in both their amino- and carboxy-terminal domains, and high binding affinities $\left(K_{\mathrm{a}}=10^{9}-10^{11} \mathrm{~mol} / \mathrm{l}\right)$ 
for IGF-I and IGF-II (Baxter 1997a). The majority of the IGFs in serum are associated with the most abundant binding protein, IGFBP-3, which can combine with another protein, known as the acid-labile subunit or ALS, to form heterotrimeric complexes containing IGF, IGFBP-3 and ALS (Baxter \& Martin 1989). ALS is a leucine-rich glycoprotein of approximately $85 \mathrm{kDa}$, the protein core of which is predicted to be largely toroidal (Leong et al. 1992, Janosi et al. 1999b). It has recently been shown that ALS can also form similar ternary complexes with IGFBP-5 and IGFs (Twigg \& Baxter 1998), although IGFBP-5 complexes would be expected to be relatively minor carriers of IGFs compared with IGFBP-3, due to the 5- to 10-fold lower serum IGFBP-5 concentration (Baxter \& Martin 1986, Mohan et al. 1995).

Like IGF-I, both IGFBP-3 (Baxter \& Martin 1986) and IGFBP-5 (Ono et al. 1996) are GH-dependent proteins, and IGFBP-3 measurement in serum has been used to evaluate GH secretory status in children and adults (Blum et al. 1993, Juul et al. 1997). Synthesis of the third member of the complex, ALS, appears to occur exclusively in the liver, and is similarly dependent on GH (Dai et al. 1994), with levels in the serum of hypophysectomized rats being less than $5 \%$ of those in normal controls (Fielder et al. 1996). While serum ALS levels are also markedly GHdependent in humans (Baxter 1990), there has been limited detailed evaluation of the value of ALS as an index of GH secretory status or action, mainly because the assay has remained in very restricted use since its introduction in 1990 (Baxter 1997b). A variety of independent assay methods have recently become available, and this study was therefore designed to evaluate and compare their performance with serum samples from subjects in a variety of different physiological and pathological states.

\section{Materials and Methods}

\section{Standard ALS preparation}

ALS was isolated from human serum as previously described (Baxter et al. 1989), except that the final high-performance ion-exchange chromatography was performed on a $4.6 \times 250 \mathrm{~mm}$ Bakerbond PEI column (Phenomenex, Torrance, CA, USA). Recombinant human ALS was produced in Chinese hamster ovary $(\mathrm{CHO})$ cells at Genentech (San Francisco, CA, USA). The protein concentrations of native and recombinant human ALS were determined by quantitative amino acid analysis. The calculated molecular mass of ALS, based on its predicted amino acid sequence, is $63.1 \mathrm{kDa}$, but both the native and recombinant proteins appear as a glycoprotein doublet of $84-86 \mathrm{kDa}$ by SDS-PAGE. Based on these observations, we assume here that $1 \mathrm{nmol}$ ALS is equal to $63.1 \mu \mathrm{g}$ nonglycosylated protein or $85 \mu \mathrm{g}$ glycosylated protein. For the purpose of comparison, all
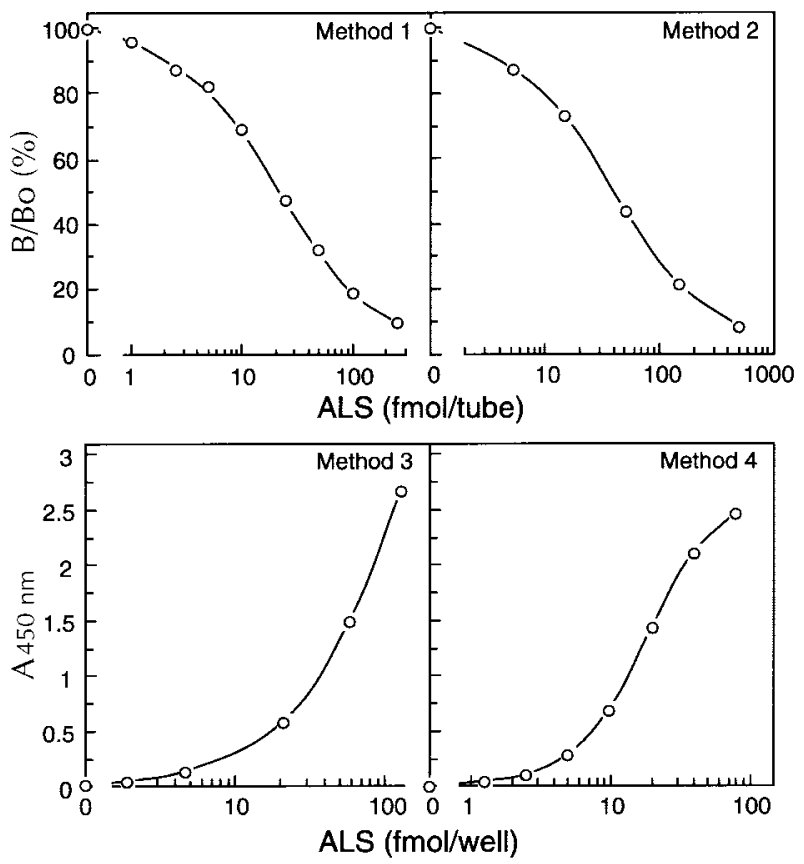

Figure 1 Representative standard curves for the four immunoassay methods. For Methods 1 and 2, B/B o represents the ratio of radioactivity bound in the presence of standard $(B)$ to that bound in the absence of standard $\left(B_{0}\right)$, where both $B$ and $B_{0}$ have been corrected for nonspecific binding (NSB). Method 1: $B_{0}=42 \%$ of total radioactivity, $\mathrm{NSB}=3.6 \%$; Method $2: \mathrm{B}_{\mathrm{o}}=45 \%$ of total radioactivity, $\mathrm{NSB}=1 \cdot 6 \%$. For Methods 3 and 4 , blank absorbance (less than $0 \cdot 1$ Absorbance unit) has been subtracted. $100 \mathrm{fmol}=8.5 \mathrm{ng}$ glycosylated ALS.

results are expressed in molar units $(100 \mathrm{nmol} / 1=8.5 \mathrm{mg} / 1$ glycosylated ALS).

Assay methods

Method 1 This is a conventional in-house radioimmunoassay first described in 1990 (Baxter 1990). This assay uses a rabbit polyclonal antibody (designated AL3) raised against human serum ALS. In brief, serum samples $(25 \mu \mathrm{l}$ of a 1:100 dilution) or standards were incubated for $16 \mathrm{~h}$ at $22{ }^{\circ} \mathrm{C}$ with ${ }^{125}$ I-labeled ALS (approx. 10000 c.p.m., $1 \mathrm{ng}$ ) and ALS antiserum at a final concentration of 1:100 000, in a total volume of $0.5 \mathrm{ml}$. Separation was by precipitation with goat anti-rabbit immunoglobulin $\mathrm{G}(\operatorname{IgG})$ and polyethylene glycol. Method 1, calibrated in molar units, covers an analytical range of 1-250 fmol/tube (0.085$21.3 \mathrm{ng} /$ tube $)$, equivalent to $4-1000 \mathrm{nmol} / 1 \quad(0.34-$ $85 \mathrm{mg} / \mathrm{l})$ in serum samples assayed at $25 \mu \mathrm{l}$ of a $1: 100$ dilution.

Method 2 This is a commercial radioimmunoassay (Bioclone Australia Pty. Limited, Sydney, NSW, Australia) using a rabbit polyclonal antibody raised against human 
Table 1 Estimates of within- and between-assay precision of the 4 assay methods

\begin{tabular}{|c|c|c|c|c|c|c|}
\hline & Within-assa & cision & & Between a & ecision & \\
\hline & Low & Medium & High & Low & Medium & High \\
\hline Method 1 & & & & & & \\
\hline CV (\%) & $6 \cdot 6$ & 3.9 & 1.9 & $13 \cdot 4$ & $6 \cdot 7$ & $7 \cdot 9$ \\
\hline$n$ & 10 & 10 & 10 & 10 & 10 & 10 \\
\hline Method 2 & & & & & & \\
\hline$n$ & 22 & 22 & 22 & 39 & 39 & 39 \\
\hline Method 3 & & & & & & \\
\hline Mean \pm S.D. $(\mathrm{nmol} / \mathrm{l})$ & $19 \cdot 4 \pm 1 \cdot 2$ & $90 \cdot 8 \pm 6 \cdot 8$ & $343 \cdot 2 \pm 13 \cdot 2$ & $26 \cdot 1 \pm 2 \cdot 2$ & $92 \cdot 9 \pm 2 \cdot 6$ & $354 \cdot 5 \pm 31 \cdot 4$ \\
\hline CV (\%) & $6 \cdot 1$ & $7 \cdot 5$ & $3 \cdot 8$ & $8 \cdot 6$ & $2 \cdot 8$ & 8.9 \\
\hline$n$ & 8 & 8 & 8 & 9 & 9 & 9 \\
\hline
\end{tabular}

serum ALS (Senese et al. 1997). The protocol was broadly similar to that of Method 1, except that serum samples were added as $100 \mu \mathrm{l}$ of a 1:200 dilution, approx. $2.5 \mathrm{ng}$ ALS tracer ( 25000 c.p.m.) were used, and separation of bound from free radioactivity depended on the use of magnetizable beads coated with an anti-rabbit second antibody. Method 2, expressed in molar units, covers an analytical range of $5 \cdot 3-503 \mathrm{fmol} /$ tube $(0 \cdot 45-42 \cdot 8 \mathrm{ng}$ / tube), equivalent to $10 \cdot 6-1006 \mathrm{nmol} / 1(0 \cdot 90-85 \cdot 5 \mathrm{mg} / \mathrm{l})$ in serum samples assayed at $100 \mu \mathrm{l}$ of a 1:200 dilution.

Method 3 This is a commercial two-site enzyme-linked immunosorbent assay (ELISA) (DSL Inc., Webster, TX, USA) using goat antisera raised against synthetic aminoand carboxy-terminal peptides of human ALS (Khosravi et al. 1997). In brief, standards and samples were pretreated

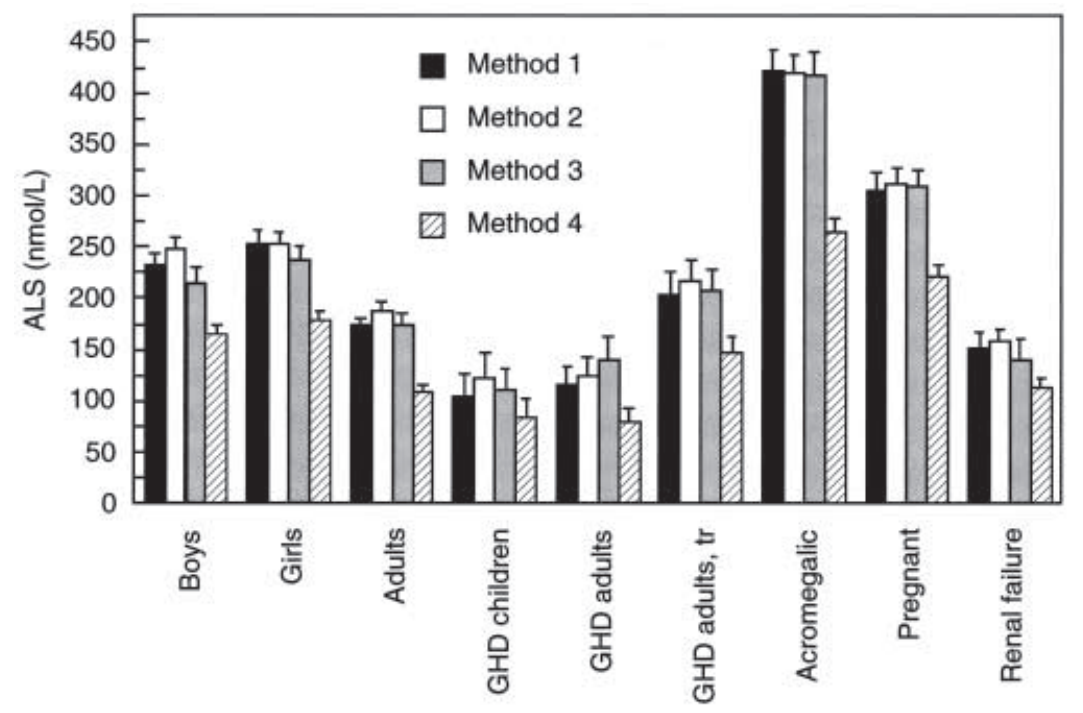

Figure 2 Mean values \pm S.E.M. for ALS measured by four methods, as indicated, in sera from groups of normal boys $(n=15)$, girls $(n=16)$, adults $(n=10)$, GH-deficient (GHD) children $(n=10), \mathrm{GHD}$ adults, either untreated $(n=21)$ or treated $(\operatorname{tr}, n=11)$ with $\mathrm{GH}$, acromegalic adults $(n=22)$, pregnant women $(n=10)$, and adults with chronic renal failure $(n=10)$. 


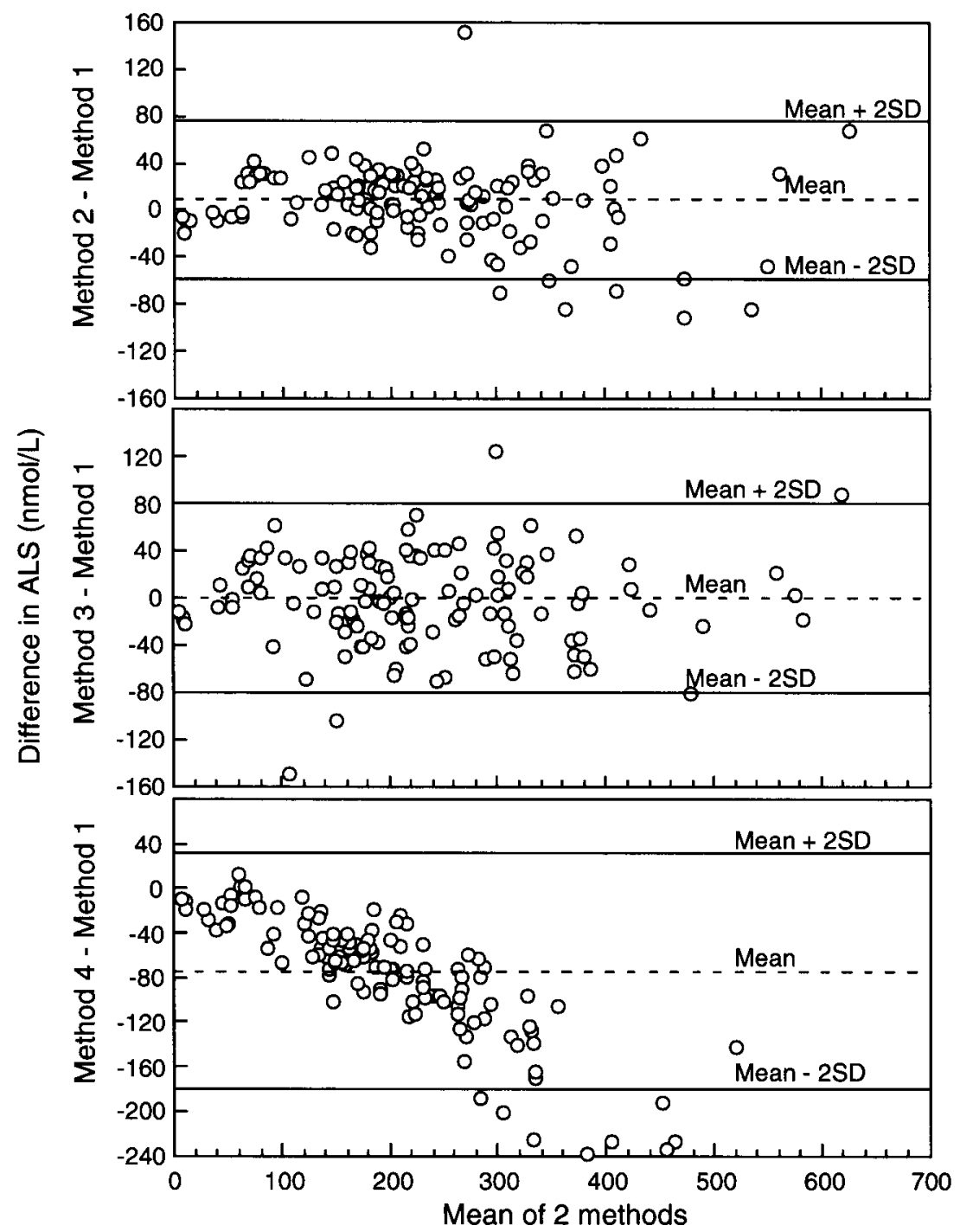

Figure 3 Difference plots showing the relationship between ALS values, in nmol/l, for all 125 subjects in the study, measured using Method 1, and values measured by Methods 2 (top), 3 (middle) and 4 (bottom).

in SDS to optimize their immunoreactivity, and aliquots ( $20 \mu \mathrm{l}$ of a 1:100 dilution) were incubated in microtiter plates coated with capture antibody for $1 \mathrm{~h}$ at $22^{\circ} \mathrm{C}$. The standard solution was made in an assay buffer matrix containing partially purified ALS from human serum as previously described (Khosravi et al. 1997), calibrated against the same natural (glycosylated) ALS reference preparation as in Methods 1 and 2. Enzyme-labeled detection antibody was added, incubated at $22{ }^{\circ} \mathrm{C}$ for $30 \mathrm{~min}$, wells were aspirated and washed, chromogen solution was added, and color development stopped after $10 \mathrm{~min}$. Absorbances were read on a plate reader at $450 \mathrm{~nm}$. The Method 3 standards, calibrated in mass units expressed as glycosylated ALS, range from $0 \cdot 16-11 \mathrm{ng} /$ well (1.9-129 fmol/well), equivalent to $0.8-55 \mathrm{mg} / 1$ $(9 \cdot 4-650 \mathrm{nmol} / \mathrm{l})$ in serum samples assayed at $20 \mu \mathrm{l}$ of a 1:100 dilution.

Method 4 This is a two-site ELISA developed at Genentech Inc. (South San Francisco, CA, USA) using monoclonal antibodies raised against recombinant human (rh) ALS. Standards (rhALS) and diluted samples (50 $\mu \mathrm{l}$ of 1:50, 1:150, 1:450 and 1:1350 dilutions) were added to microtiter plate wells coated with capture antibody, and incubated for $2 \mathrm{~h}$ at $22{ }^{\circ} \mathrm{C}$ together with enzymelabeled detection antibody. After washing, chromogen solution was added and color development was stopped after $15 \mathrm{~min}$. Absorbances were read on a plate reader at 
$450 \mathrm{~nm}$. Method 4 standards, when converted from their calibrated protein mass, ignoring glycosylation, to the equivalent mass of glycosylated ALS, cover the range of $0 \cdot 11-6 \cdot 75 \mathrm{ng} /$ well $(1 \cdot 2-79 \mathrm{fmol} /$ well $)$, equivalent to $0 \cdot 32-20 \cdot 2 \mathrm{mg} / 1 \quad(3 \cdot 7-238 \mathrm{nmol} / \mathrm{l})$ in serum samples assayed at $50 \mu \mathrm{l}$ of a 1:150 dilution.

\section{Serum samples}

The 125 serum samples used in this trial were selected to allow the best comparison of different assay methods on sera containing a wide range of ALS concentrations, and not to provide reference ranges for various clinical conditions. All samples were obtained with the permission of the relevant institutional ethics committees. They comprised samples from healthy non-pregnant adults $(n=10)$, pregnant women $(n=10)$, healthy girls aged $10-17$ years $(n=16)$, healthy boys aged $10-15$ years $(n=15)$, untreated GH-deficient adults $(n=21)$, GH-deficient adults replaced with hGH $(0 \cdot 125 \mathrm{U} / \mathrm{kg} /$ week, s.c.) for 6 months $(n=11)$, GH-deficient children $(n=10)$, adults with acromegaly $(n=22)$, and adults with chronic renal failure $(n=10)$.

\section{Data analysis}

Method 1 was published in 1990 (Baxter 1990) and was the only existing ALS assay for some 8 years after its introduction. It is therefore regarded as the de facto standard method, and was used as the reference method in this study. Mean values for groups were compared by analysis of variance followed by Fisher's Protected Least Significant Difference (PLSD) test, performed using StatView 4.02 (Abacus Concepts, Berkeley, CA, USA). Slopes and intercepts of regression lines, with 95\% confidence limits, were calculated using UltraFit 3.0 (Biosoft, Cambridge, Cambs, UK).

\section{Results}

Typical standard curves for the 4 methods are shown in Fig. 1. For the RIA methods (Methods 1 and 2), the response variable is $\mathrm{B} / \mathrm{B}_{0}$, the radioactivity bound in the presence of each standard, expressed as a percentage of that bound in the absence of standard. For the ELISA methods (Methods 3 and 4), the response variable is absorbance at $450 \mathrm{~nm}$. Methods 1 and 4 gave half-maximal responses (estimated as the half-maximal measured response) in the range $15-20 \mathrm{fmol} /$ tube or well, whereas for Methods 2 and 3 , the half-maximal responses were in the range 40-50 fmol/tube or well. Estimates of the within- and between-assay precision for the 4 assay methods are summarized in Table 1.

A set of 125 serum samples was run in all four assay methods. For the 125 samples, the mean value ( \pm s.D.) obtained by Method 1 was $230 \cdot 6 \pm 124 \cdot 7 \mathrm{nmol} / 1$; for
Table 2 Comparisons between values for all samples, determined by Methods 2, 3, or 4, and values determined by Method 1 . Values are shown with $95 \%$ confidence limits

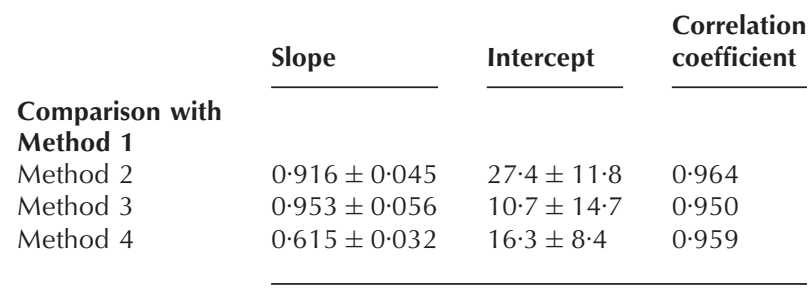

Method 2, $238.6 \pm 118.4 \mathrm{nmol} / 1 ;$ for Method 3, $230 \cdot 3 \pm 125 \cdot 0 \mathrm{nmol} / 1 ;$ and for Method 4, 158.1 \pm $79.9 \mathrm{nmol} / 1$ (significantly lower than the means for the other three methods, $P<0 \cdot 0001)$. Figure 2 shows the mean values \pm s.E.M. for each assay method, for all subject groups. In each case, means for Methods 1-3 were in close agreement, whereas the mean for Method 4 was lower.

Figure 3 shows difference plots comparing results for all samples obtained by Methods 2, 3 and 4 with those obtained by Method 1, which is regarded as the reference method. Only the comparison between Methods 1 and 4 shows evidence of a systematic dose-dependent discrepancy, consistent with a difference in standardization of the two methods. The same data obtained by Methods 2, 3 and 4 were also compared with those obtained by Method 1 in simple linear regression analyses. The slopes and intercepts of the regression lines derived from these analyses are presented in Table 2, with 95\% confidence limits. Despite the different methodologies (radioimmunoassay and ELISA), and the use of antibodies raised against natural protein, recombinant protein or synthetic part-sequence peptides, all methods gave remarkably consistent results, with values for the correlation coefficient $(r)$ for the various comparisons of at least 0.950 , and intercepts close to zero. Slopes were close to unity for the comparisons Method 2 vs Method 1 and Method 3 vs Method 1. In contrast, the slope for the comparison Method 4 vs Method 1 was 0.615. Together with the lower overall mean value for Method 4, this is consistent with the difference plots in suggesting a discrepancy in calibration between the standard used in Method 4 and those used in the other methods.

When the rhALS standard used in Method 4 was calibrated against the same native ALS reference preparation used to calibrate the other Method standards, values obtained for unknown samples were elevated by a factor of 1.73 , which would normalize the slope of the calibrated Method 4 vs Method 1 comparison plot to approximately $1 \cdot 0$ (data not shown).

To examine possible differences between the four methods in greater detail, comparisons were performed on subsets of samples representing various categories of subjects. Figure 4 shows difference plot analyses for the 41 


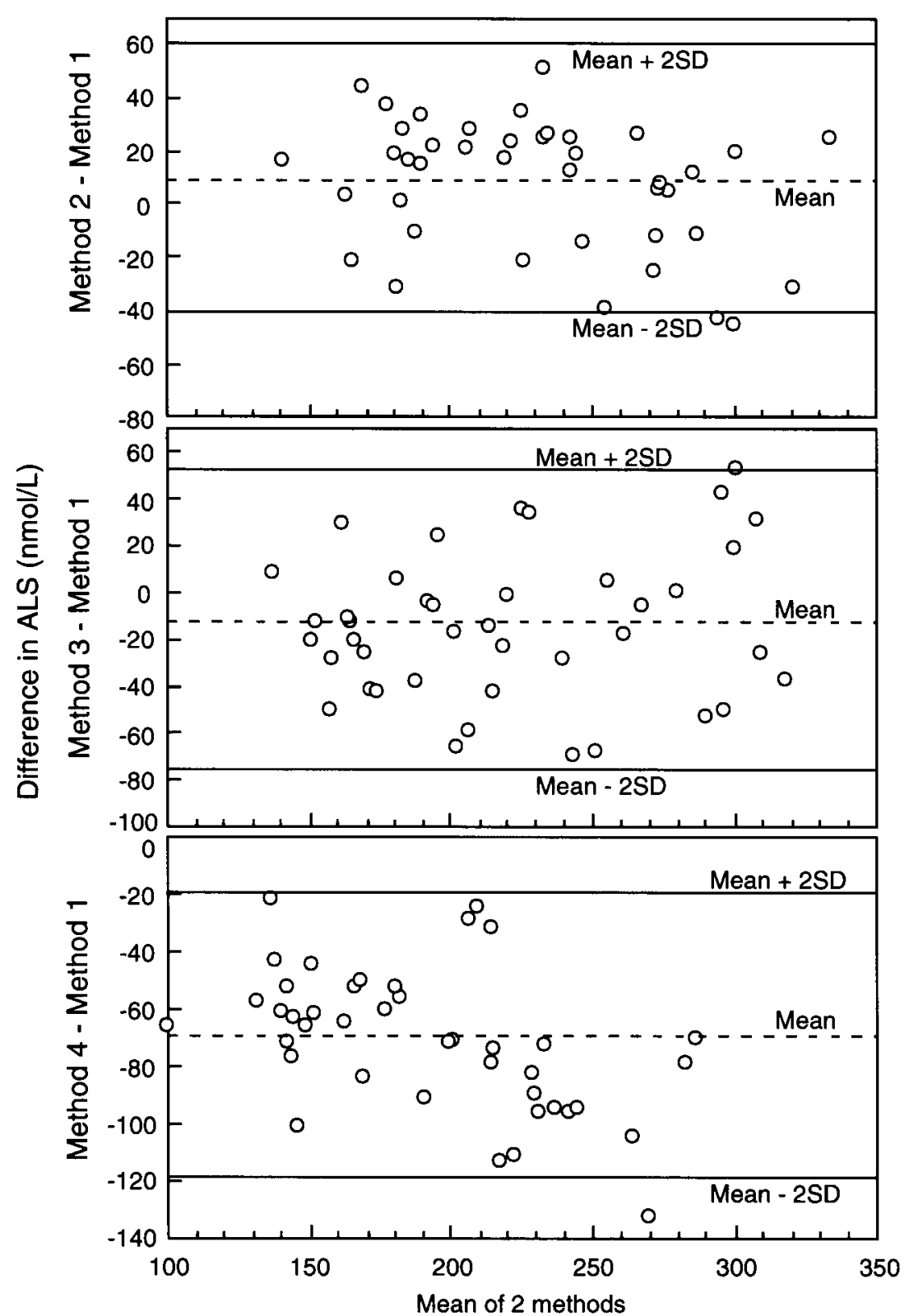

Figure 4 Difference plots showing the relationship between ALS values, in nmol/l, for 41 normal children and adults, measured using Method 1, and values measured by Methods 2 (top), 3 (middle) and 4 (bottom).

normal, nonpregnant subjects. As seen in Fig. 3, only the comparison between Methods 1 and 4 shows evidence of a systematic dose-dependent discrepancy, consistent with the standardization difference. For the 41 normal, nonpregnant subjects' samples, the mean value ( \pm s.D.) obtained by Method 1 was $226.3 \pm 53.5 \mathrm{nmol} / \mathrm{l}$; for Method 2, $236.1 \pm 45.7 \mathrm{nmol} / 1$; for Method 3, $213.9 \pm 57.8 \mathrm{nmol} / 1 ;$ and for Method 4, 157.2 \pm $41.6 \mathrm{nmol} / 1$. As shown in Table 3 , correlation coefficients derived from linear regression analyses were high (in the range 0.84-0.89), although the slope of the Method 2 vs Method 1 comparison was only $0 \cdot 76$, due to a large $\mathrm{Y}$-axis intercept. Similar comparisons for groups of subjects with $\mathrm{GH}$ disorders (all GH-deficient subjects, all acromegalic subjects) are shown in Table 3; again, correlation coefficients were high (in the range $0 \cdot 82-0 \cdot 98$ ), and the slopes of regression lines for comparisons of Method 4 vs Method 1 were consistently lower than for comparisons between 
Table 3 Comparisons between values for various subject groups, determined by Methods 2, 3, or 4, and values determined by Method 1 . Values are shown with $95 \%$ confidence limits

\begin{tabular}{|c|c|c|c|c|}
\hline & $\begin{array}{l}\text { Comparison } \\
\text { with Method } 1\end{array}$ & Slope & Intercept & Correlation coefficient \\
\hline \multicolumn{5}{|l|}{$\begin{array}{l}\text { Subject } \\
\text { group }\end{array}$} \\
\hline \multirow{3}{*}{ Normal $^{\mathrm{a}}(n=41)$} & Method 2 & $0 \cdot 760 \pm 0 \cdot 127$ & $64 \cdot 0 \pm 29 \cdot 5$ & $0 \cdot 889$ \\
\hline & Method 3 & $0 \cdot 908 \pm 0 \cdot 190$ & $8 \cdot 5 \pm 44 \cdot 1$ & $0 \cdot 840$ \\
\hline & Method 4 & $0 \cdot 694 \pm 0 \cdot 114$ & $0 \cdot 1 \pm 26 \cdot 4$ & $0 \cdot 893$ \\
\hline \multirow[t]{3}{*}{ GH-deficient ${ }^{\mathrm{b}}(n=42)$} & Method 2 & $0 \cdot 987 \pm 0 \cdot 071$ & $14 \cdot 0 \pm 11 \cdot 3$ & 0.976 \\
\hline & Method 3 & $1 \cdot 031 \pm 0 \cdot 123$ & $10 \cdot 4 \pm 19 \cdot 6$ & 0.937 \\
\hline & Method 4 & $0 \cdot 718 \pm 0 \cdot 055$ & $0 \cdot 8 \pm 8 \cdot 8$ & 0.972 \\
\hline \multirow[t]{3}{*}{ Acromegalic $(n=22)$} & Method 2 & $0 \cdot 772 \pm 0 \cdot 250$ & $93 \cdot 4 \pm 107 \cdot 9$ & $0 \cdot 821$ \\
\hline & Method 3 & $0.985 \pm 0.211$ & $2 \cdot 4 \pm 91 \cdot 1$ & $0 \cdot 908$ \\
\hline & Method 4 & $0 \cdot 587 \pm 0 \cdot 182$ & $17 \cdot 5 \pm 78 \cdot 5$ & 0.832 \\
\hline \multirow[t]{3}{*}{ Pregnant $(n=10)$} & Method 2 & $0 \cdot 294 \pm 0.522^{\mathrm{NS}}$ & $222 \cdot 8 \pm 161 \cdot 6$ & $0 \cdot 417$ \\
\hline & Method 3 & $0 \cdot 559 \pm 0 \cdot 410$ & $140 \cdot 0 \pm 126 \cdot 9$ & $0 \cdot 744$ \\
\hline & Method 4 & $0 \cdot 535 \pm 0 \cdot 229$ & $58 \cdot 2 \pm 70 \cdot 8$ & $0 \cdot 885$ \\
\hline \multirow[t]{3}{*}{ Chronic renal failure $(n=10)$} & Method 2 & $0 \cdot 724 \pm 0 \cdot 183$ & $47 \cdot 4 \pm 28 \cdot 9$ & 0.956 \\
\hline & Method 3 & $0.406 \pm 1.067^{\mathrm{NS}}$ & $78 \cdot 8 \pm 168 \cdot 8$ & $0 \cdot 297$ \\
\hline & Method 4 & $0 \cdot 560 \pm 0 \cdot 166$ & $29 \cdot 2 \pm 26 \cdot 3$ & $0 \cdot 940$ \\
\hline
\end{tabular}

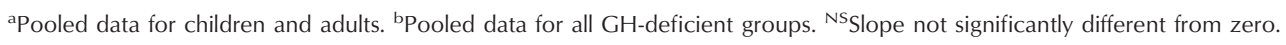

Methods 2 or 3 vs Method 1, consistent with a systematic effect of assay calibration for Method 4.

The final comparisons were for samples from pregnant subjects and patients with chronic renal failure, both conditions where proteolysis of IGFBP-3 is reported to occur (Hossenlopp et al. 1990, Powell et al. 1993). In these relatively small sample groups, greater discrepancies among some of the methods were seen than in the other patient groups (Table 3). For the pregnancy sera, the Method 2 vs Method 1 comparison showed a slope not significantly different from zero, and for the chronic renal failure sera, the Method 3 vs Method 1 comparison had a non-significant slope. However, it should be noted that for both the pregnancy and chronic renal failure sample groups, the mean values obtained for the 10 sera in each group were virtually identical for Methods $1-3$, and were systematically lower only for Method 4 (Fig. 2).

\section{Discussion}

This study demonstrates strong overall correlations among the values obtained in the four ALS immunoassay methods tested, despite the different analytical approaches used, and the likely differences in the epitopes recognized by the antibodies. This uniformity of results suggests that, at least for healthy subjects and those with GH disorders, ALS probably circulates in a substantially intact form; i.e. there are no significant concentrations of ALS fragments, or alternative conformations of ALS, that might be detected differentially by the different antibodies. Methods 1,2 , and
4 detect denatured (i.e. acidified) ALS poorly, if at all, and are believed to detect complexed ALS as effectively as free ALS, whereas Method 3 relies on the denaturation (by SDS) of ALS to increase detection by 200-fold (Khosravi et al. 1997). The close parallel in the values for different patient groups detected by these different methodological approaches indicates that most or all of the ALS in the circulation is in the native conformation, since a significant concentration of denatured ALS would lead to systematically lower values by Method 1 compared with Method 3 .

Despite the strong correlations among the four methods for most samples, it was evident that results obtained using Method 4 were systematically lower than those for the other three methods, suggesting a difference in calibration. Standards used in Methods 1-3 were all calibrated against the same reference preparation of natural ALS, whereas Method 4 used a different primary standard of recombinant human ALS derived from $\mathrm{CHO}$ cells. Concentrations of both primary standards were determined by quantitative amino acid analysis in the same laboratory. However, the recombinant protein showed $\sim 1.73$ times the immunoreactivity of the natural protein, and parallelism with native ALS, when the native and recombinant proteins were compared in Method 4 (data not shown).

As the full amino acid sequence of human ALS was deduced from the cDNA sequence, with only partial sequencing of the natural protein (Leong et al. 1992), the possibility of a difference in primary structure between serum-derived and recombinant ALS cannot be excluded. However, quantitative amino acid analyses of the natural and recombinant proteins have suggested that both 
molecules have the amino acid composition predicted by the cDNA. A more likely difference between the two preparations is in the extensive glycosylation, which accounts for some $25 \%$ of the apparent molecular mass of $85 \mathrm{kDa}$ of the fully glycosylated protein (Baxter et al. 1989). This carbohydrate appears to play an essential role in ternary complex formation (Janosi et al. 1999a). Further physico-chemical characterization will be required to define the apparent differences between rhALS and native ALS which our data suggest. Nevertheless, the present comparison has demonstrated that all four methods are capable of distinguishing ALS values in a wide variety of patient samples to a similar degree.

The two sample groups in which some discrepancies among methods was seen were those from pregnant subjects, and from subjects with renal failure. These groups were included in the analysis as examples of 'difficult' samples, since IGFBP physiology is abnormal in both conditions. In pregnancy, a serum protease is known to cause partial proteolysis of IGFBP-3 (Hossenlopp et al. 1990); however, it still forms a normal ternary complex with ALS and appears to transport IGFs normally (Suikkari $\&$ Baxter 1992). The functional abnormality in pregnancy IGFBP-3 is thus still controversial. In contrast, the proteolyzed form of IGFBP-3 seen in renal failure serum has an obvious functional abnormality since it circulates at a low molecular weight and fails to complex with ALS (Powell et al. 1993, Baxter et al. 1994).

Although there may be some disruption to ALS complexes in pregnancy, the apparent discrepancy in ALS values between Methods 1 and 2 when assaying pregnancy sera is, nevertheless, difficult to explain, since the ALS antisera used were raised against the same natural ALS preparation and are believed to have similar specificities (data not shown). The discrepancy is probably exaggerated by the small sample number and the clustered ALS concentrations in these samples; indeed, when one of the 10 data points was omitted, the slope of the regression line between these two sets of data became significant, with a correlation coefficient of 0.768 . In contrast, the discrepancy between Methods 1 and 3 when measuring renal failure samples did not appear to be due to a single outlying point. Method 3 uses antisera raised against amino- and carboxy-terminal peptides of ALS, whereas Methods 1, 2, and 4 use antibodies raised against the full-length protein. This may result in discrepancies among the four methods in rare samples containing fragments or truncated forms of ALS, with Method 3 more likely to detect only full-length molecules. Whether amino- or carboxy-terminally truncated fragments of ALS actually circulate in renal failure or any other condition is unknown, but this is clearly an area for further investigation.

The clinical utility of serum ALS determination remains to be fully evaluated (Baxter 1997b). As a GH-dependent, hepatocyte-derived protein its measurement may provide a unique index of hepatic $\mathrm{GH}$ response in conditions such as disorders of $\mathrm{GH}$ secretion, catabolic states, and hepatic cirrhosis (Baxter 1997b). Serum ALS levels show significant rises in response to $\mathrm{GH}$ administration in $\mathrm{GH}$ deficiency (De Boer et al. 1996) and to GH secretagogues in prolonged critical illness (Van den Berghe et al. 1998). As illustrated by the values obtained in the present comparative study, ALS levels differ markedly among samples from subjects with GH deficiency, normal GH status, and GH excess, so that its measurement may prove useful as a marker of GH secretory status. While recent studies support this idea (Juul et al. 1998), the ultimate acceptance of the measurement of ALS as an important tool in clinical practice will await a more extensive evaluation of its diagnostic value in many laboratories. The recent release of several commercial ALS assays should certainly accelerate progress towards this goal.

\section{Acknowledgements}

The authors thank Lisa Caris, John Hanson, Denise Harrison, Philip Lester, Kurt Schroeder and Chris Swenson at Genentech.

\section{References}

Albertsson-Wikland K \& Rosberg S 1992 Methods of evaluating spontaneous growth hormone secretion. In Functional Endocrinologic Diagnostics in Children and Adolescents, pp 76-101. Ed MB Ranke. Mannheim: J \& J Verlag.

Baxter RC 1990 Circulating levels and molecular distribution of the acid-labile $(\alpha)$ subunit of the high molecular weight insulin-like growth factor-binding protein complex in normal subjects. Journal of Clinical Endocrinology and Metabolism 70 1347-1353.

Baxter RC 1997a Molecular aspects of insulin-like growth factor binding proteins. Advances in Molecular and Cellular Endocrinology 1 123-159.

Baxter RC $1997 b$ The binding protein's binding protein - clinical applications of acid-labile subunit (ALS) measurement. Journal of Clinical Endocrinology and Metabolism 82 3941-3943.

Baxter RC \& Martin JL 1986 Radioimmunoassay of growth hormone-dependent insulin-like growth factor binding protein in human plasma. Journal of Clinical Investigation 78 1504-1512.

Baxter RC \& Martin JL 1989 Structure of the $M_{\mathrm{r}} 140000$ growth hormone-dependent insulin-like growth factor binding protein complex: determination by reconstitution and affinity labeling. Proceedings of the National Academy of Sciences of the USA 86 6898-6902.

Baxter RC, Martin JL \& Beniac VA 1989 High molecular weight insulin-like growth factor binding protein complex. Purification and properties of the acid-labile subunit from human serum. Journal of Biological Chemistry $26411843-11848$.

Baxter RC, Dai J, Holman S \& Lewitt MS 1994 Determinants of complex formation between IGFBP-3 and the acid-labile subunit. In The Insulin-like Growth Factors and their Regulatory Proteins, pp 227-235. Eds RC Baxter, PD Gluckman \& RG Rosenfeld. Amsterdam: Elsevier.

Blum WF, Albertsson-Wikland K, Rosberg S \& Ranke MB 1993 Serum levels of insulin-like growth factor-I (IGF-I) and IGF binding protein-3 reflect spontaneous growth hormone secretion. Journal of Clinical Endocrinology and Metabolism 76 1610-1616. 
Dai J, Scott CD \& Baxter RC 1994 Regulation of the acid-labile subunit of the insulin-like growth factor complex in cultured rat hepatocytes. Endocrinology 135 1066-1072.

De Boer H, Blok GJ, Popp-Snijders C, Stuurman L, Baxter RC \& Van der Veen EA 1996 Monitoring of growth hormone replacement therapy in adults, based on measurement of serum markers. Journal of Clinical Endocrinology and Metabolism $\mathbf{8 1}$ 1371-1377.

DonaghyAJ \& Baxter RC 1996 Insulin-like growth factor bioactivity and its modification in growth hormone resistant states. Bailliere's Clinical Endocrinology and Metabolism 10 421-446.

Fielder PJ, Mortensen DL, Mallet P, Carlsson B, Baxter RC \& Clark RG 1996 Differential long-term effects of insulin-like growth factor-I (IGF-I), GH, and IGF-I plus GH on body growth and IGF binding proteins in hypophysectomized rats. Endocrinology 137 1913-1920.

Hoffman DM, O'Sullivan AJ, Baxter RC \& Ho KY 1994 Diagnosis of growth hormone deficiency in adults. The Lancet $\mathbf{3 4 3}$ 1064-1068.

Hossenlopp P, Segovia B, Lassarre C, Roghani M, Bredon M \& Binoux M 1990 Evidence of enzymatic degradation of insulin-like growth factor-binding proteins in the $150 \mathrm{~K}$ complex during pregnancy. Journal of Clinical Endocrinology and Metabolism 71 797-805.

Humbel RE 1990 Insulin-like growth factors-I and -II. European Journal of Biochemistry 190 445-462.

Janosi J, Firth S, Bond J, Baxter R \& Delhanty P 1999a N-linked glycosylation and sialylation of the acid-labile subunit. Role in complex formation with insulin-like growth factor (IGF)-binding protein-3 and the IGFs. Journal of Biological Chemistry 274 $5292-5298$

Janosi J, Ramsland P, Mott M, Firth S, Baxter R \& Delhanty P 19996 The acid-labile subunit of the serum insulin-like growth factor-binding protein complexes. Structural determination by molecular modeling and electron microscopy. Journal of Biological Chemistry $27423328-23332$.

Juul A, Kastrup KW, Peresen SA \& Skakkerbæk NE 1997 Growth hormone $(\mathrm{GH})$ provocative retesting of 108 young adults with childhood-onset GH deficiency and the diagnostic value of insulin-like growth factor-I (IGF-I) and IGF-binding protein-3. Journal of Clinical Endocrinology and Metabolism 82 1195-1201.

Juul A, Møller S, Mosfeldt-Laursen E, Rasmussen M, Scheike T, Pedersen S, Kastrup K, Yu H, Mistry J, Rasmussen S, Müller J, Henriksen J \& Skakkebaek N 1998 The acid-labile subunit of human ternary insulin-like growth factor binding protein complex in serum: hepatosplanchnic release, diurnal variation, circulating concentrations in healthy subjects, and diagnostic use in patients with growth hormone deficiency. Journal of Clinical Endocrinology and Metabolism 83 4408-4415.

Khosravi MJ, Diamandi A, Mistry J, Krishna RG \& Khare A 1997 Acid-labile subunit of human insulin-like growth factor-binding protein complex: measurement, molecular and clinical evaluation. Journal of Clinical Endocrinology and Metabolism 82 3944-3951.

Leong SR, Baxter RC, Camerato T, Dai J \& Wood WI 1992 Structure and functional expression of the acid-labile subunit of the insulin-like growth factor-binding complex. Molecular Endocrinology 6 870-876.

Mohan S, Libanati C, Dony C, Lang K, Srinivasan N \& Baylink DJ 1995 Development, validation and application of a radioimmunoassay for insulin-like growth factor binding protein-5 in human serum and other biological fluids. Journal of Clinical Endocrinology and Metabolism 80 2638-2645.

Ono T, Kanzaki S, Seino Y, Baylink DJ \& Mohan S 1996 Growth hormone $(\mathrm{GH})$ treatment of $\mathrm{GH}$-deficient children increases serum levels of insulin-like growth factors (IGFs), IGF-binding protein-3 and -5 , and bone alkaline phosphatase isoenzyme. Journal of Clinical Endocrinology and Metabolism 81 2111-2116.

Powell DR, Liu F, Baker B, Lee PDK, Belsha CW, Brewer ED \& Hintz RL 1993 Characterization of insulin-like growth factor binding protein-3 in chronic renal failure serum. Pediatric Research 33 136-143.

Ranke MB \& Haber P 1992 Growth hormone stimulation tests. In Functional Endocrinologic Diagnostics in Children and Adolescents, pp 61-75. Ed MB Ranke. Mannheim: J \& J Verlag.

Rosenfeld RG 1996 Biochemical diagnostic strategies in the evaluation of short stature: the diagnosis of insulin-like growth factor deficiency. Hormone Research 46 170-173.

Senese A, Georgiakakis N, Lowe K \& Svejkar M 1997 Development and clinical trial of a commercial radioimmunoassay for the detection of acid-labile subunit. 4th International Symposium on Insulin-like Growth Factors, Tokyo, p 152 (Abstract).

Suikkari A-M \& Baxter RC 1992 Insulin-like growth factor binding protein-3 is functionally normal in pregnancy serum. Journal of Clinical Endocrinology and Metabolism 74 177-183.

Twigg SM \& Baxter RC 1998 Insulin-like growth factor (IGF) binding protein-5 forms an alternate ternary complex with IGFs and the acid-labile subunit. Journal of Biological Chemistry $\mathbf{2 7 3}$ 6074-6076.

Van den Berghe G, De Zegher F, Baxter RC, Veldhuis JD, Wouters P, Schetz M, Verwaest C, Van der Vorst E, Lauwers P, Bouillon R \& Bowers CY 1998 Neuroendocrinology of prolonged critical illness: effects of exogenous thyrotropin-releasing hormone and its combination with growth hormone secretagogues. Journal of Clinical Endocrinology and Metabolism 83 309-319.

Received 12 August 1999

Accepted 30 November 1999 